\title{
EUROPA A ŚWIADECTWO EDYTY STEIN
}

Fenomenowi ducha Europy poświęcony został osobny tom przygotowany przez Centrum Badań Edyty Stein. Dzisiejsze moje wystąpienie wywodzi się $\mathrm{w}$ jakimś sensie $\mathrm{z}$ ducha tego opracowania. $\mathrm{Z}$ uwagi jednak na to, że nie jestem filozofem, moje podejście będzie bardziej dotykało aspektów politycznych i prawno-państwowych.

Mówiąc o Edycie Stein i Europie, niejako automatycznie przychodzi skojarzenie z decyzją Jana Pawła II o ogłoszeniu jej współpatronką starego kontynentu. Jedynym patronem Europy do czasów Jana Pawła II, formalnie ogłoszonym przez Pawła VI w 1964 r. (list apostolski Pacis Nuntius), był święty Benedykt. Papież z Polski podejmuje w tym zakresie wyraźną - by użyć dzisiejszych określeń medialnych - ofensywę. W jakimś sensie zaskakuje świat, wskazując na nowych patronów Europy. Było to niewątpliwie odpowiedzią na stan ducha religijnego Europy, na zjawisko, które określa się jako „zaćmienie Boga”, a które zanalizował w swoim tekście abp Marek Jędraszewski¹. Proces „zaciemniania Boga”, eliminowania Go z życia publicznego, ulegał pogłębieniu w ostatnim ćwierćwieczu XX wieku, niestety w sposób szczególny zwłaszcza w Europie zachodniej.

Nie ulega jednak wątpliwości, że ogłaszanie patronów Europy było także widomym wyrazem realizowania swoistej polityki europejskiej przez Jana Pawła II i zarazem przypominania o istnieniu Boga, wskazywania na Jego obecność w historii.

${ }^{1}$ M. Jedraszewski, Tchnać nowego ducha w Stary Kontynent. Święci Patroni Europy, w: Fenomen ducha Europy, red. M. Jędraszewski, M. Loba, D. Jewdokimow, Poznań 2010, s. 105-106. 
Z tego względu zarówno osoby, jak i czas wyboru, czas ogłaszania tych patronów był precyzyjnie przez Jana Pawła II dobierany w kontekście wydarzeń europejskich. Listem apostolskim Egregiae virtutis z 31 grudnia 1980 roku papież ogłasza patronami Europy świętych Cyryla i Metodego. Mimo wielości świętych pochodzących z zachodniej Europy, Jan Paweł II decyduje się na ogłoszenie patronami Europy tych mniej znanych, mniej popularnych, co mogło wywoływać zdziwienie. Podkreślano wielokrotnie, mówił o tym też sam papież, że czyni to $\mathrm{w}$ roku 1500 rocznicy urodzin św. Benedykta. Mam jednak głębokie przekonanie, że Jan Paweł II kierował się także innymi motywami. Dobór bowiem postaci i daty jest jednoznaczny. Jest to przecież rok Solidarności, a papież niewątpliwie żył tymi wydarzeniami w Polsce i ich konsekwencjami. To był czas, kiedy Jana Paweł II miał już wyraźną wizję przyszłego poszerzania się Europy, jednoczenia Europy wschodniej i zachodniej, którego politycy jeszcze nie przeczuwali albo nie dopuszczali takiej wizji do siebie. Papież odwoływał się do metafory „dwóch płuc Europy" - przekaz zatem był jasny. Wyraźnie mówił o tym pięć lat później, w 1985 roku, kiedy Europa jeszcze cały czas była podzielona. W encyklice Slavorum Apostoli pisał: "Ich [Świętych Cyryla i Metodego - przyp. H.S.] dzieło stanowi wybitny wkład w tworzenie wspólnych korzeni Europy, które dzięki swej trwałości i żywotności stanowią jeden z najmocniejszych punktów odniesienia, jakich nie może pominąć żaden poważny wysiłek zmierzający do zaprowadzenia nowej jedności kontynentu w naszych czasach [podkr. H.S.]"2. Papież użył wręcz określenia „,jedność kontynentu” w czasie, kiedy takie pojęcie w sferze politycznej nie funkcjonowało. To świadczy o wizjonerstwie Jana Pawła II.

Tej przyszłej jedności patronować mieli właśnie św. Cyryl i Metody. Wybór patronów, którzy pochodzą ze wschodniej Europy, był zatem wyraźnym znakiem, przekazem. Przekazem o konieczności powrotu do jednej Europy, ale zarazem podkreśleniem równoprawności obu jej części wschodniej i zachodniej. Tak zwana Europa zachodnia przestała już być miejscem przechowywania wartości chrześcijańskich. Europa wschodnia, mimo iż zmagała się przez kilkadziesiąt lat z przymusową ateizacją, zachowała je znacznie silniej. Papież dostrzegał wartość, jaką Europa wschodnia może zaproponować zachodniej. Poprzez uczynienie tych właśnie świętych współpatronami Europy papież w szczególny sposób pragnął upodmiotowić tę wschodnią część, będąca przez tyle lat poza głównym nurtem jednoczącej się Europy.

\footnotetext{
2 Jan Paweł II, Encyklika Slavorum Apostoli $z$ dnia 2 czerwca 1985, podaję za: www.vatican.va.
} 
Św. Cyryl i Metody byli pionierami ewangelizacji na Wschodzie. Poprzez ich wybór Jan Paweł II wskazał wyraźnie, że ta część Europy, która musiała walczyć o prawo do wiary w okresie komunizmu, ma coś do zaoferowania tej drugiej - właśnie w sferze przekazu chrześcijaństwa i ewangelizacji, tak jak czynili to Cyryl i Metody w ich epoce.

Na ogłoszenie kolejnych współpatronów Europy czekaliśmy bez mała dwadzieścia lat. Dotychczasowe podziały europejskie się rozpadły. Europa poszukiwała nowej formuły wspólnotowego zorganizowania się. I znowu zarówno dobór osób współpatronów, jak i czas są precyzyjnie przez Jana Pawła dobrane. Jest to już okres zasadniczej debaty o jednoczeniu Europy. Od dziesięciu lat trwa poszerzanie Europy i rozmowa o jej przyszłości. Kolejny raz, już teraz bardzo konkretnie, wraca pytanie o korzenie europejskie i fundament jednoczącego się kontynentu. Swoim Motu proprio z dnia 1 października 1999 roku (w przeddzień nowego tysiąclecia) Ojciec Święty uroczyście ogłasza kolejnych współpatronów, a precyzyjniej - współpatronki Europy: św. Katarzynę ze Sieny, św. Brygidę Szwedzką i św. Teresę Benedyktę od Krzyża. W tym przypadku przekaz wydaje się jasny: kobiety. W nowej Europie toczy się debata o roli kobiet, o ich większym udziale w życiu publicznym, o kształcie i formie tego udziału. Pojawiają się jednak też akcenty niebezpieczne związane $\mathrm{z}$ tworzeniem tak zwanych nowych praw, które mają rzekomo kobietę wyzwolić od dotychczasowego zamknięcia $\mathrm{w}$ tradycyjnej rolach. Lansuje się zbyt jednowymiarowy model roli kobiety w społeczeństwie, oparty na zasadzie radykalnie pojętego indywidualizmu, indywidualizmu sprowadzającego się właściwie do egoizmu, a więc jakby zaprzeczającego jednej z istotnych cech kobiety, jaką od zawsze było otwarcie na innych. Wizja Jana Pawła II jest odmienna. Idzie zarówno pod prąd radykalnego feminizmu, jak i postrzegania feminizmu jako wroga. Jego widzenie wzajemnych uwarunkowań pomiędzy jednostką a społeczeństwem i tym samym pomiędzy kobietą a mężczyzną jest bardziej kompleksowe, bardziej pogłębione. Jan Paweł II stara się przywrócić właściwą proporcję rzeczy. Nie walka, ale komplementarność; nie zatarcie różnicy płci, ale wyraźne rozróżnienie dwóch płci; nie zamiana ról, ale współdziałanie i uzupełnianie się?. Jego koncepcja ",nowego feminizmu” wspiera kobiety.

Jednym z elementów jego polityki (nie waham się użyć tego słowa) w tym zakresie jest ogłoszenie kobiet współpatronkami Europy. Jak pisze:

${ }^{3}$ Szerzej zob. H. Suchocka, Kilka uwag o roli kobiety w świetle "Listu do biskupow Kościoła katolickiego o współdziałaniu mężczyzny i kobiety w Kościele i w świecie”, opublikowanego przez Kongregację Doktryny Wiary, w: Powołanie Kobiety, Kobiecoś, Uniwersytet, Świętość, red. W. Ciak OCD, Poznań 2006, s. 31-32, 
"Ich świętość bowiem urzeczywistniła się w określonych kontekstach historycznych i geograficznych, które sprawiają, że są to postaci szczególnie ważne dla kontynentu europejskiego. ${ }^{\prime \prime}$

Wybranie kobiet, Europejek, wśród nich Edyty Stein, jest wskazaniem przez papieża na rolę kobiet we współczesnej Europie. I w tym sensie Edyta była mu tak bliska. Była Europejką, była świętą żyjąca współcześnie w Europie, była kobietą zabiegająca o prawa kobiet. W jakimś sensie była feministką - w takim rozumieniu, w jakim używał go Jan Paweł II i któremu sprzyjał. Myślenie o kobiecie, feminizmie było w jego wypadku inne niż to właściwe nurtowi, który w latach dziewięćdziesiątych stawał się dominujący. Był to bowiem okres zderzania się (agresywnego) feminizmu lansowanego przez kulturę globalną z feminizmem Edyty Stein i Jana Pawła II. Ogłaszając św. Teresę współpatronką Europy, Jan Paweł II podkreślił fakt, że swoim życiem ukazała ona możliwości rozwoju społecznego kobiety. Jak zaznaczył: „Edyta prowadziła [...] życie bardzo aktywne, wypełnione nie tylko poszukiwaniami duchowymi, ale także pracą naukową i dydaktyczną, którą wykonywała z podziwu godnym poświęceniem. Na szczególne uznanie zasługuje - ze względu na epokę - jej działalność na rzecz postępu społecznego kobiety. Św. Teresa jako patronka Europy miała wskazywać pewien model aktywności kobiety współczesnej, Europejki [podkr. H.S.]"5.

Bycie kobietą to jeden z czynników, który decydował o wybraniu Edyty jako współpatronki Europy obok dwóch innych świętych kobiet. Posiadała ona jednak jeszcze i inne cechy, których brakowało pozostałym współpatronkom.

Postać św. Teresy Benedykty od Krzyża była idealnym „modelem” na patrona Europy. Uosabiała w sobie cechy, które były istotne dla kształtowania tożsamości europejskiej: była Niemką, Żydówką, chrześcijanką i Europejką. Była Europejką we współczesnym rozumieniu tego słowa. Jej europejskość odgrywała przy tym wyborze papieża ważną rolę. Była Żydówką w sensie narodowym i religijnym, ale urodziła się w Niemczech, we Wrocławiu - wówczas mieście niemieckim (ale bardzo wielokulturowym), w momencie natomiast ogłaszania ją patronką - należącym już do Polski. Już chociażby ten fakt odzwierciedlał wszystkie meandry kształtowania się powojennej Europy. Św. Teresa Benedykta od Krzyża ogniskowała w sobie

4 Jan Paweł II, List Apostolski Motu Proprio ogłaszający św. Brygidę Szwedzka, św. Katarzyne ze Sieny $i$ św. Teresę Benedyktę od Krzyża wspótpatronkami Europy, Rzym, 1 października 1999, www.opoka.org.pl/biblioteka/W/WP/jan_pawel_ii/motu/patronki_europy.html [dostęp: 10.11.2013].

${ }^{5}$ Por. E. Stein, Kobieta. Jej zadanie według natury i łaski, tłum. I.J Adamska OCD, Tczew Pelplin 1999. 
to, co było charakterystyczne (istotne) dla przemian Europy w XX wieku w kwestiach narodowych. Ale nie tylko. Była także pomostem pomiędzy dwoma religiami. Jan Paweł II pisze: „Całym swoim życiem - jako myślicielka, mistyczka i męczenniczka - przerzuciła jak gdyby most między swoim żydowskim pochodzeniem a wiarą w Chrystusa, prowadząc z niezawodną intuicją dialog ze współczesną myślą filozoficzną"6.

Była też ofiarą, ale zarazem znakiem tego, co było w tej Europie najbardziej haniebne w XX w. Jako patronka Europy ma być przypomnieniem i przestrogą, stać się „symbolem przemian dokonujących się w człowieku, kulturze i religii, w których kryje się sam zarodek tragedii i nadziei kontynentu europejskiego"7. To ona, poprzez swoje męczeństwo, jak pisze papież - w obliczu straszliwej hańby Shoah - stała się rzeczniczką racji Boga i człowieka.

Edyta jest znakiem głębokiej potrzeby ekumenizmu, który Kościół nieustannie rozwija, a którego Europa bardzo potrzebuje. Przecież dialog ekumeniczny, dialog międzyreligijny miał stać się jednym ze znaków charakterystycznych jednoczącej się Europy. A Edyta Stein była symbolem przekraczania podziałów narodowych i religijnych, a zarazem nieodrzucania, nieodcinania się od swoich własnych korzeni, o co przecież w Europie dzisiejszej tak bardzo chodzi. To niezwykle ważny element przy tworzeniu wspólnej Europy - mocne zakotwiczenie, osadzenie w swojej tradycji, czerpanie siły ze swoich korzeni do tworzenia czegoś nowego, do bycia otwartym na dialog z innymi. Człowiek pozbawiony korzeni, odrzucający je, jest słaby, nie ma siły argumentacji wobec innych. Z niczego nie wyrasta i nic za nim nie stoi. Edyta, stając się chrześcijanką, nigdy nie wyrzekła się swoich korzeni żydowskich. Wyrosła z nich, aby wzrastać w chrześcijaństwie. Edyta, jak pisze Jan Paweł II, to: „zadatek nowego zbliżenia między żydami a chrześcijanami, które zgodnie z życzeniem wyrażonym przez Sobór Watykański II doprowadziło do wzajemnego otwarcia, budzącego nadzieje na przyszłość" 8 .

W jej postaci możemy dostrzec niezwykle silną personifikację korzeni judeochrzescijańskich, które stanowią jeden z kluczowych elementów tożsamościowych Europy, a które w trakcie budowy tej Europy, zwłaszcza w debacie konstytucyjnej ostatnich lat, jakby zostały zapomniane. Przyszłość Europy możemy budować z zaufaniem tylko wtedy, jeśli będzie ona bezpiecznie zakotwiczona $\mathrm{w}$ naszej kulturze i w naszej wspólnocie. Jeżeli nie

\footnotetext{
${ }^{6}$ Jan Paweł II, List Apostolski Motu Proprio..., dz. cyt.

7 Tamże.

8 Tamże.
} 
dostrzeżemy wartości i znaczenia, jakie dla Europy ma jednoznaczne i jasne odniesienie do źródeł naszej tożsamości, potrzeba tworzenia wspólnego projektu europejskiego stale będzie niezrozumiała9.

Mówiąc o europejskim kontekście Edyty Stein, nie można pominąć tak ważnej kwestii, jaką są prawa człowieka. W jej postaci uosabia się najokrutniejszy przykład całkowitej negacji praw człowieka, przekreślenia tego, co immanentne dla osoby ludzkiej, jej godności i egzystencji. I znowu, według słów Jana Pawła II: „Patrząc dziś na Teresę Benedyktę od Krzyża, dostrzegamy $\mathrm{w}$ tym świadectwie niewinnej ofiary $\mathrm{z}$ jednej strony naśladowanie Baranka-Żertwy oraz protest przeciw wszelkim przejawom łamania podstawowych praw człowieka"10.

W tym kontekście ogłoszenie św. Teresy patronką sprawia, że staje się ona symbolem-przestrogą dla współczesnej Europy. Jest swoistym przykładem á rebours traktowania praw człowieka. Takie postrzeganie ma głębokie zakorzenienie $\mathrm{w}$ personalizmie Jana Pawła II, wyrażającym się w stałym podkreślaniu znaczenia osoby ludzkiej i traktowania godności osoby ludzkiej jako centrum odniesienia dla wszystkich innych praw. Jan Paweł II ostro kontestuje deformacje praw człowieka, to jest tworzenie jako rzekomych "praw człowieka” takich praw, które są sprzeczne z istotą godności osoby ludzkiej, stanowiąc istotne zagrożenie dla struktury współczesnego społeczeństwa. Wprowadził on do języka międzynarodowego określenie „cywilizacja śmierci". Stąd postać św. Teresy jako patronki-przestrogi.

Jan Paweł II angażował się silnie, aby tak zwane "prawa” uderzające $\mathrm{w}$ prawo do życia nie uzyskały charakteru standardów uniwersalnych. W tym sensie jego wizja organizacji społeczeństwa, państwa, a także struktury ponadpaństwowej jest zbieżna z wizją św. Teresy. Jest ona zakotwiczona na uporządkowaniu wewnętrznym człowieka i na uporządkowaniu relacji między ludźmi. Jest także oparta na "dobrym prawie”.

I sądzę, że właśnie ta kwestia wymaga głębszej uwagi. Zdaję sobie zarazem sprawę z całej wieloznaczności tego pojęcia i złożoności problemu, który tutaj mogę tylko zarysować. Mam wrażenie, że myślenie św. Teresy o Europie w kontekście rozumienia prawa jest współcześnie niedocenione. Można natomiast zakładać, że było ono dobrze znane Janowi Pawłowi II i stanowiło ważny czynnik przy decyzji o uznaniu jej za patronkę Europy. Jest to pewne wyczucie intuicyjne, albowiem wprost takiego odniesienia nie znalazłam.

\footnotetext{
9 Por. wypowiedź B. Aherna, w: L'incontro con il Papa richiamo dei valori al centro del progetto europeo, intervento del Primo Ministro d'Irlanda Bertie Ahern, „L'Osservatore Romano", 9 lipca 2005 r.

10 Jan Paweł II, List Apostolski Motu Proprio..., dz. cyt.
} 
Pewne odniesienie do tego problemu znajdujemy w Motu proprio w następujących słowach:

\begin{abstract}
Aby zbudować nową Europę na trwałych fundamentach, nie można jedynie odwoływać się do interesów ekonomicznych, które czasem łączą, kiedy indziej jednak dzielą, lecz trzeba się oprzeć na autentycznych wartościach, mających podstawę $\mathrm{w}$ powszechnym prawie moralnym, wszczepionym w serce każdego człowieka. Gdyby Europa mylnie utożsamiła zasadę tolerancji i szacunku dla wszystkich z obojętnością etyczną i sceptycyzmem wobec nieodzownych wartości, weszłaby na niezwykle niebezpieczną drogę, na której prędzej czy później pojawiłyby się pod nową postacią najbardziej przerażające widma z jej przeszłości [podkr. H.S.]11.
\end{abstract}

I w tym kontekście dotykamy niezwykle istotnych kwestii poruszanych w tekstach Edyty Stein. Jej rozważania w tym zakresie mają fundamentalne znaczenie i są niezwykle aktualne dla debat toczących się obecnie. Powiedziałabym, że do tych wszystkich spraw, którym tradycyjnie już przypisuje się patronowanie św. Teresy jako współpatronki Europy - to jest tolerancji, dialogu międzyreligijnego, przekraczania uprzedzeń narodowościowych należy także dodać jej patronowanie nad dobrym prawem, nad stanowieniem prawa. Czy w takim widzeniu można dopatrzyć się pewnego nadużycia, pewnego zawodowego skrzywienia prawniczego? Może nie zgodzą się z tym filozofowie, a także i pewnie nie wszyscy prawnicy, ja jednak chciałabym $\mathrm{w}$ niej widzieć taką patronkę. I jest to nie tylko czysty prawniczy wishful thinking, ale wniosek wynikający z analizy jej tekstów.

Edyta Stein prowadziła logiczny wywód dotyczący relacji prawa stanowionego i prawa znajdującego się ponad stanowionym. Wkraczamy tutaj $\mathrm{w}$ delikatną materię nazwania tego innego prawa, ponadstanowionego. W literaturze włoskiej używa się określenia diritto puro, prawo czyste. Intuicyjnie zatem jest to "prawo naturalne", choć nie zostało ono tak wprost nazwane. Edyta zatem rozumiała wagę problemu, który jest obecnie tak kontrowersyjny zarówno $\mathrm{w}$ debacie wewnętrznej państw, jak i w sferze prawotwórstwa europejskiego.

Stale aktualne jest pytanie, co stanowi materię regulacji prawnej? Spór dotyczący tych relacji jest niezwykle aktualny i przekłada się na ostry spór polityczny, nie zawsze mający dobre zakotwiczenie filozoficzne czy aksjologiczne. $\mathrm{W}$ różnych okresach historii prawotwórstwa pojawiały się $\mathrm{w}$ koncepcje pozytywistyczne, czy nawet skrajnie pozytywistyczne, negujące odniesienia do innych wartości, do innego prawa poza prawem stanowionym. Prawnicy zdają sobie bowiem sprawę $\mathrm{z}$ trudności $\mathrm{w}$ zdefiniowaniu tego

11 Tamże. 
„innego" prawa. Doktryna prawa naturalnego napotyka na ogromne trudności aplikacyjne w prawie stanowionym. Jego odrzucenie prowadzi jednak do zupełnego woluntaryzmu prawnego. Św. Teresa rozumiała to doskonale. W swoich pismach dawała mocne podstawy teoretyczne konstrukcji relacji prawa stanowionego i prawa czystego (diritto puro) i w tym kontekście konstrukcji państwa prawa. Rozróżniała to, co w literaturze określa się jako ius i lex. I w nawiązaniu do tego rozróżniała dwa rodzaje państwa.

Każdemu państwu, w świetle konstytucji, przypisany jest pewien akt woli, na mocy którego wydaje on akty prawne. Ta wola skierowana może być na tworzenie bądź państwa stricte legalistycznego, bądź też państwa prawa, czyli takiego które zmierza do harmonizacji prawa pozytywnego $\mathrm{z}$ istniejącym a priori „prawem czystym”. E. Stein w studium o państwie (Una ricerca sullo Stato) przeciwstawia wyraźnie państwo legalistyczne, przywiązane tylko do prawa stanowionego, państwu prawa ${ }^{12}$. Zatem tylko państwo, które w swojej działalności prawotwórczej uwzględnia prawo naturalne, harmonizuje prawo stanowione z prawem naturalnym, jest godne miana państwa prawa. Niewątpliwie jej rozważania są odzwierciedleniem debaty, jaka toczyła się wówczas wśród prawniczych specjalistów w Niemczech. Są też jednak zarazem jakby profetyczną wizją tego, co nastąpi w państwie nazistowskim. Państwo skrajnie legalne (oparte tylko na prawie pozytywnym) przeciwstawione zostanie $w$ istocie państwu prawa.

Rozważania E. Stein wpisują się wyraźnie w debatę, jaka toczyła się $\mathrm{w}$ latach dziewięćdziesiątych, w okresie transformacji, w państwach postkomunistycznych, kiedy dokonywano zasadniczych zmian $\mathrm{w}$ prawie, a zwłaszcza w konstytucji. Pojawiło się wtedy pytanie o zakres swobody ustawodawcy i to zarówno w wymiarze konstytucyjnym, jak i ustaw zwykłych. Sprowadzało się ono właściwie do pytania, czy prawo stanowione powinno się do „czegoś" odnosić, do jakiegoś wzorca aksjologicznego, czy też ustawodawca (a zwłaszcza ustrojodawca) jest nieskrępowany w zakresie swobody regulacji? Doświadczenia przeszłości, kruchość podstaw, na jakich opierały się konstytucje systemów autorytarnych, wywoływały potrzebę tego rodzaju odniesień i poszukiwań. Dyskusja ta była niewątpliwie pilnie śledzona przez Jana Pawła II.

Jak już pisałam $\mathrm{w}$ innym miejscu, $\mathrm{w}$ takich momentach przełomu prawo naturalne staje się odniesieniem ładu, jest postrzegane jako prawo sprawie-

12 E. Stein, Una ricerca sullo Stato, cyt. za: L. Avitabile, Diritti umani e fenomenologia dello Stato in Edith Stein, in Colloqui sulla dignita umana, Roma 2008, s. 12. 
dliwe, co oznacza, że w razie konfliktu norm może to prowadzić do odrzucenia prawa pozytywnego ${ }^{13}$.

$\mathrm{Z}$ koncepcji diritto puro wywodzą się, według E. Stein, prawa nienegocjowane. Jest to kolejna konstrukcja - prawa nienegocjowane - która wywołuje współcześnie dużą dyskusję emocjonalną. Termin „prawa nienegocjowane" używany był często przez Jana Pawła II podczas debat europejskich dotyczących praw człowieka, zwłaszcza w kontekście prawa do życia. Myślę, że to właśnie $\mathrm{w}$ tym rozróżnieniu zakotwiczony jest także obraz relatywizmu przedstawiony przez Benedykta XVI. Ratzinger pisze:

Odcięcie się od korzeni chrześcijańskich nie jest wyrazem najwyższej tolerancji, która $\mathrm{w}$ ten sam sposób szanuje wszystkie kultury, nie chcąc żadnej uprzywilejować. [...] Odrzucenie odniesienia do Boga nie jest wyrazem tolerancji, która chce ochronić wyznania nieteistyczne i godność ateistów i agnostyków, ale raczej wyrazem świadomości, która chciałaby zupełnie wymazać Boga z życia publicznego ludzkości i umieścić Go w subiektywnym kręgu resztek minionych kultur. Relatywizm, który jest punktem wyjścia tego wszystkiego, staje się w ten sposób dogmatyzmem, który uważa siebie za posiadacza ostatecznego poznania rozumu i uznaje całą resztę tylko jako w gruncie rzeczy przestarzałą fazę ludzkości, która może być odpowiednio relatywizowana ${ }^{14}$.

Koncepcja diritto puro E. Stein jest właśnie konstrukcją pozwalająca uniknąć pułapki relatywizmu.

Sądzić należy też, że fiasko uchwalenia pierwszej konstytucji europejskiej w dużej mierze wynikało z faktu, iż liderzy, dyskutując jej treść, postanowili zamknąć się $\mathrm{w}$ debacie zogniskowanej wyłącznie na prawie pozytywnym. W sytuacji, w której dyskutuje się pierwszą konstytucję europejską, pierwszą konstytucję wspólnej Europy, nie da się uniknąć problemu odniesienia do wartości, do ducha europejskości, do diritto puro według Edyty Stein. W takiej sytuacji eliminacja czy też przemilczanie jednej z tych wartości może być odebrane jako próba ideologicznej manipulacji. To musiało doprowadzić do fiaska.

I jeszcze jeden ważny wątek w rozważaniach E. Stein o państwie, który ma ścisły związek z tworzeniem wspólnej Europy. Jest to wywód dotyczący tworzenia struktur ponadpaństwowych i koncepcji związanych z ograniczaniem suwerenności. E. Stein nie była przeciwniczką tworzenia struktur

${ }^{13}$ H. Suchocka, Problemy wokót postulatu sprawiedliwości w powojennej Europie, w: O prawach człowieka w podwójna rocznicę Paktów, księga pamiątkowa w hotdzie prof. Annie Michalskiej, red. T. Jasudowicz, C. Mika, Torun 1996, s. 269.

14 J. Ratzinger, Europa Benedykta w kryzysie kultur, tłum. W. Dzieża, Częstochowa 2005, s. $62-63$. 
ponadnarodowych. Już w listach do Ingardena zwracała uwagę na tworzenie się wspólnoty kulturowej ponad granicami państw. W tym sensie była Europejką. Myślę, że ta jej wizja została trafnie ujęta w Motu Proprio w słowach: „wznieść nad starym kontynentem sztandar szacunku, tolerancji i otwartości, wzywający wszystkich ludzi, aby się wzajemnie rozumieli i akceptowali, niezależnie od różnic etnicznych, kulturowych i religijnych, oraz by starali się budować społeczeństwo prawdziwie braterskie"15.

Sądzę, że jej konstrukcja tworzenia struktury ponadpaństwowej wymaga głębokiej analizy w warunkach współczesnych. Dodam, że nie może być ona oderwana od jej koncepcji dotyczącej relacji pomiędzy prawem stanowionym a prawem naturalnym. Państwo może zrezygnować z części swojej suwerenności, jeśli decyduje się na tworzenie struktury ponadpaństwowej. Jeśli to jest wynikiem jego woli. Natomiast aby było państwem prawa, nie może stosować całkowitego woluntaryzmu w stanowieniu prawa. Musi odnosić je do prawa innego ponad stanowionym. Koncepcja E. Stein jest w tej kwestii jasna i jednoznaczna.

Sądzę, że europejska myśl Edyty Stein, zwłaszcza jej rozważania o państwie, wymaga dokładnej analizy w świetle współczesnych debat europejskich o państwie i kształcie struktury ponadnarodowej. Jest to nasze zobowiązanie wobec patronki Europy.

\section{Europe and the Testimony of Edith Stein}

Summary

This article, written from the legal and constitutional perspective, seeks to explore John Paul II's reasons that made him announce Edith Stein the co-patroness of Europe. The author begins with recalling prior patrons of Europe that is Saint Benedict and Saint Cyril and Methodius, and juxtaposes it with further pope's decision to add three saint women to them. It is also an occasion to discuss questions like: woman rights and request for their greater participation in the public sphere, the concept of 'new feminism', national and religious issues, ecumenical and interreligious dialogue, JudeoChristian roots of the Europe, human rights and 'civilisation of death' - all related with Edith Stein. The last part of the article is devoted to the reflection on law: the natural and the so-called 'good law', as well as its establishment.

${ }^{15}$ Jan Paweł II, List Apostolski Motu propprio..., dz. cyt. 